\title{
ANALISIS KEBUTUHAN PENGEMBANGAN VIDEO PEMBELAJARAN MATA KULIAH PROGRAM LINIER
}

\author{
Nourma Pramestie Wulandari ${ }^{1}$, Nilza Humaira Salsabila ${ }^{2}$, Nani Kurniati ${ }^{3}$ \\ 1,2,3Program Studi Pendidikan Matematika FKIP Universitas Mataram \\ 1nourmapw@unram.ac.id
}

\begin{abstract}
Linear Programming is a course under the scope of algebra that must be mastered by mathematics education students. The low ability to solve linear programming problems can affect student performance when they become a teacher. This study aims to analyze the need for developing learning videos in Linear Programming courses for students of the Mathematics Education Study Program. The method used is development research which consists of Preliminary Analysis, Product Prototype, and Assessment. The research subjects were 30 students in the 7th semester of mathematics education and had attended online Linear Programming lectures in the previous semester. Data were collected by conducting written tests, questionnaires, and interviews and analyzed quantitatively descriptively. The results of the written test analysis showed that the students' ability to solve linear programming problems was low. Based on interviews, it is also known that students are not enough just to learn through modules and virtual meetings. Students tend to need learning videos/records to repeat explanations when studying the material independently. Therefore, there is a great need for learning videos that can optimize online learning of Linear Programming courses.
\end{abstract}

Keywords: Learning Media, Learning Video, Linear Programming, Preliminary Analysis

\begin{abstract}
ABSTRAK
Program Linier merupakan mata kuliah di bawah ruang lingkup aljabar yang harus dikuasai oleh mahasiswa pendidikan matematika. Rendahnya kemampuan menyelesaikan masalah program linier dapat mempengaruhi kinerja mahasiwa saat sudah menjadi seorang guru. Penelitian ini bertujuan untuk menganalisis kebutuhan pengembangan video pembelajaran pada mata kuliah Program Linier bagi mahasiswa Program Studi Pendidikan Matematika. Metode yang digunakan adalah penelitian pengembangan yang terdiri atas Analisis Pendahuluan, Prototipe Produk, dan Asesmen. Subjek penelitian yaitu 30 orang mahasiswa semester 7 pendidikan matematika dan telah mengikuti perkuliahan Program Linier secara daring pada semester sebelumnya. Data dikumpulkan dengan melakukan tes tulis, angket, dan wawancara serta dianalisis secara deskriptif kuantitatif. Hasil analisis tes tulis menunjukkan bahwa kemampuan mahasiswa dalam menyelesaikan masalah program linier tergolong rendah. Berdasarkan wawancara juga diketahui bahwa mahasiswa tidak cukup hanya belajar melalui modul dan pertemuan virtual yang
\end{abstract}


dilakukan. Mahasiswa cenderung memerlukan video/rekaman pembelajaran untuk mengulang penjelasan saat mempelajari materi secara mandiri. Oleh karena itu, sangat diperlukan video pembelajaran yang dapat mengoptimalisasi pembelajaran mata kuliah Program Linier secara daring.

Kata Kunci: Analisis Kebutuhan, Media Pembelajaran, Program Linier, Video Pembelajaran

\section{A. Pendahuluan}

Pembelajaran secara daring bukan lagi menjadi hal yang asing selama terjadinya pandemi Covid-19. Dampak pada berbagai sendi kehidupan membuat setiap orang berlomba untuk beradaptasi dengan keadaan saat ini. Bentuk adaptasi dalam bidang pendidikan terlihat dengan maraknya platform penyedia kelas-kelas online untuk mendukung pembelajaran siswa selama pembelajaran jarak jauh (PJJ) dilaksanakan. Sejalan dengan hal tersebut, media pembelajaran berbasis teknologi dan informasi turut menjadi ranah adaptasi yang dilakukan oleh pendidik dari berbagai jenjang pendidikan. Sebagai seorang guru yang professional, tentunya selalu kreatif dan penuh inovasi dalam mendesain pembelajaran agar dapat membantu keberhasilan belajar siswa bukan lagi hal yang asing untuk selalu dikembangkan (Wulandari dkk, 2020).

Media pembelajaran adalah wadah atau alat bantu pembelajaran yang dapat membantu seorang pendidik dalam mentransfer suatu materi agar lebih mudah untuk dipahami siswa (Nurrita, 2018; Supriyono, 2018). Terdapat berbagai jenis media pembelajaran yang dapat digunakan oleh guru, misal alat peraga, powerpoint interaktif, Lembar Kerja Peserta Didik (LKPD), peta konsep, powerpoint informatif, permainan edukasi, dan video pembelajaran. Lebih lanjut, berdasarkan beberapa hasil penelitian, diketahui bahwa video pembelajaran dapat membuat proses pembelajaran lebih efektif, menghemat waktu, materi lebih mudah dipahami, serta meningkatkan minat, motivasi dan prestasi belajar siswa (Agustini \& Ngarti, 2020; Candralaela et al., 2017; Nurwahidah et al., 2021; Purwanti, 2015).

Video pembelajaran menjadi salah satu media pembelajaran yang paling dibutuhkan dalam pembelajaran matematika selama masa pandemi Covid-19 (Purbayanti 
dkk, 2020). Karakteristik matematika yang memiliki kajian berupa objek abstrak sering menjadikan seseorang berasumsi bahwa matematika sulit dipahami sehingga memacu turunnya motivasi seseorang untuk belajar (Salsabila dkk, 2020; Wulandari dkk, 2021). Oleh karena itu, dibutuhkan perantara/media seperti video pembelajaran yang dapat membawa objek kajian matematika ini terkesan nyata untuk dipelajari, terutama selama PJJ seperti saat ini. Terlebih, hasil penelitian Lu'luilmaknun dkk (2020) menunjukkan bahwa siswa lebih banyak menggunakan video pembelajaran dalam mempelajari matematika.

Mata kuliah di bawah ruang lingkup aljabar yang diajarkan pada program studi pendidikan matematika salah satunya yakni Program Linier. Materi dalam mata kuliah ini wajib dikuasai oleh mahasiswa pendidikan matematika. Terlebih saat sudah menjadi seorang guru, mahasiswa harus dapat mengajar dengan benar kepada siswa. Materi program linier termasuk dalam kompetensi dasar yang akan diajarkan di jenjang SMA. Implikasinya, apabila kemampuan menyelesaikan masalah program linier seorang mahasiswa calon guru tergolong rendah, tentu dapat mempengaruhi kinerja mahasiwa saat sudah menjadi seorang guru. Oleh karena itu, meski dengan keterbatasan selama mata kuliah ini diajarkan secara daring, pendidik (dosen) harus dapat berkreasi dalam memfasilitasi ketercapaian kompetensi pada mata kuliah ini secara maksimal. Alternatif solusi yang ditawarkan yakni dengan menyediakan media pembelajaran berupa video pembelajaran sebagai pendukung perangkat pembelajaran telah tersedia.

\section{B. Metode Penelitian}

Penelitian ini merupakan penelitian pengembangan (Research \& Development) berdasarkan tiga tahap pengembangan oleh Plomp (2010). Secara lengkap, tahap penelitian pengembangan ini terdiri atas tiga tahapan, yaitu (1) Analisis Pendahuluan, (2) Prototipe Produk dan (3) Asesmen. Penelitian ini bertujuan untuk menganalisis kebutuhan pengembangan video pembelajaran mata kuliah Program Linier. Dengan kata lain, penelitian pengembangan ini berfokus pada tahap Analisis Pendahuluan. 
Analisis

pendahuluan

merupakan bagian penting dalam mengembangkan suatu video pembelajaran yang dapat membantu mahasiswa dalam mencapai tujuan pembelajaran pada mata kuliah Program Linier. Dengan kata lain, target dan sasaran dari produk yang dikembangkan dapat sesuai dengan apa yang dibutuhkan mahasiswa setelah melalui tahapan ini sebagai langkah awal (Apsari dkk, 2020). Oleh karena itu, dalam tahapan ini, peneliti juga melakukan penelitian terhadap kemampuan mahasiswa Program Studi Pendidikan Matematika pada Mata Kuliah Program Linier yang diajarkan secara daring serta hasil survei terkait pelaksanaan perkuliahan pada mata kuliah ini.

Teknik pengumpulan data dilakukan dengan memberikan tes tulis kepada 30 mahasiswa semester 7 Program Studi Pendidikan Matematika di suatu perguruan tinggi negeri di Nusa Tenggara Barat, Indonesia. Tahap selanjutnya yakni dengan pemberian angket dan wawancara. Subjek penelitian merupakan mahasiswa yang mengambil mata kuliah Program Linier dan mengikuti keseluruhan pembelajaran secara daring. Selain itu, subjek juga diberikan angket yang berisi 7 pernyataan dengan 5 alternatif jawaban yang disusun menggunakan skala pengukuran likert dan 1 pertanyaan terbuka terkait pembelajaran mata kuliah Program Linier. Selanjutnya, data dianalisis secara deskriptif kuantitatif untuk memetakan kebutuhan pengembangan video pembelajaran mata kuliah Program Linier yang diperlukan untuk membantu mahasiswa dalam melaksanakan perkuliahan secara daring.

\section{C.Hasil Penelitian dan Pembahasan} Deskripsi kemampuan subjek penelitian pada mata kuliah Program Linier

Penelitian ini menggunakan tes yang terdiri atas 5 soal berbentuk essai dan dikerjakan selama 120 menit. Soal dikerjakan secara individu dan diunggah pada batas waktu yang ditentukan. Soal-soal tersebut berkaitan dengan materi yang diajarkan dalam perkuliahan Program Linier, yakni berkaitan dengan penyelesaian masalah program linier dengan berbagai metode (metode grafik, metode simpleks, metode Big$M$, metode dua fase, dan dualitas) serta penyelesaian masalah yang 
berkaitan

dengan

masalah

transportasi. Sebelum dilakukan tes, seluruh materi telah diajarkan secara daring menggunakan platform SPADA yang dimiliki oleh perguruan tinggi di mana penelitian ini dilakukan.

Berdasarkan hasil pekerjaan partisipan, diketahui bahwa nilai ratarata yang diperoleh adalah 60.54 dengan nilai terendah 30 dan nilai tertinggi adalah 100. Modus partisipan berada pada nilai 50 . Secara umum, hanya ada 11 dari 30 partisipan yang mendapat skor di atas 50. Hal ini menunjukkan bahwa belum terlampaui separuh dari banyaknya partisipan di kelas tes yang dapat melampaui target Capaian Perkuliahan Mata Kuliah (CPMK) Program Linier. CPMK dalam mata kuliah ini yaitu setelah mengikuti perkuliahan ini diharapkan mahasiswa mampu menyelesaikan masalah yang berkaitan dengan program linier dnegan menggunakan berbagai metode, serta mampu menyelesaikan masalah yang berkaitan dengan masalah transportasi. Pemaparan ini menunjukkan bahwa kemampuan mahasiswa Prodi Pendidikan Matematika dalam menyelesaikan masalah program linier setelah diajarkan secara daring masih tergolong rendah. Kesulitan adaptasi dan keterbatasan media pembelajaran selama pembelajaran secara daring dapat berakibat pada rendahnya hasil belajar mahasiswa (Annur \& Hermansyah, 2020; Nasrah \& Muafiah, 2020).

Kebutuhan pengembangan video pembelajaran mata kuliah Program Linier

Berdasarkan hasil tes kemampuan mahasiswa dalam menyelesaiakan masalah program linier yang telah dilakukan, terlihat bahwa diperlukan suatu upaya untuk dapat meningkatkan kemampuan mahasiswa pada mata kuliah Program Linier. Sebagai calon guru, tentunya mahasiswa Program Studi Pendidikan Matematika harus dapat menguasai mata kuliah ini karena berkaitan dengan apa yang akan diajarkan kepada siswa ketika mahasiswa tersebut sudah lulus dan menjadi seorang guru. Oleh karena itu, dalam penelitian ini juga dilakukan observasi terhadap ketersediaan perangkat pembelajaran Mata Kuliah Program Linier yang dilakukan secara daring seperti pada Tabel 1 berikut.

Tabel 1 Kelengkapan Perangkat

Pembelajaran Mata Kuliah Program Linier secara Daring 


\begin{tabular}{llcc}
\hline \multirow{2}{*}{ No } & \multirow{2}{*}{ Jenis } & \multicolumn{2}{c}{ Ketersediaan } \\
\cline { 3 - 4 } & & Ya & Tidak \\
\hline 1 & Silabus & $\sqrt{ }$ & \\
2 & RPS & $\sqrt{ }$ & \\
3 & RTM & $\sqrt{ }$ & \\
4 & Buku Ajar/Modul & $\sqrt{ }$ & \\
5 & Platform Kelas Daring & $\sqrt{ }$ & \\
6 & Video Pembelajaran & \multicolumn{2}{c}{$\sqrt{ }$} \\
\hline
\end{tabular}

Berdasarkan Tabel 1, terlihat bahwa kebutuhan dalam pembelajaran mata kuliah Program Linier secara daring sudah hampir lengkap. Namun belum terdapat video pembelajaran yang diberikan pada kelas daring mata kuliah tersebut. Akibatnya, mahasiswa yang mengalami kendala jaringan ketika kelas daring berlangsung dalam pertemuan virtual akan kesulitan untuk dapat mengikuti pembelajaran. Padahal berdasarkan hasil survei, seperti yang ditunjukkan pada Gambar 1, diketahui sebanyak 46,7\% mahasiswa menyatakan setuju dan 40\% mahasiswa menyatakan sangat setuju bahwa pertemuan virtual dapat membantu mahasiwa dalam memahami materi Program Linier. Lebih lanjut, mahasiswa dengan kendala tersebut dapat mengalami kesulitan dalam memahami materi dari modul secara mandiri. Hal ini dikarenakan tidak adanya video pembelajaran maupun rekaman pertemuan virtual yang berisi penjelasan dari dosen dan juga diskusi bersama mahasiswa di kelas. Padahal, video pembelajaran yang difungsikan secara optimal dapat membantu pendidik untuk mendorong ketercapaian kompetensi pada ranah kognitif, afektif, psikomotorik, dan dapat meningkatkan kemampuan interpersonal (Nurwahidah dkk, 2021).

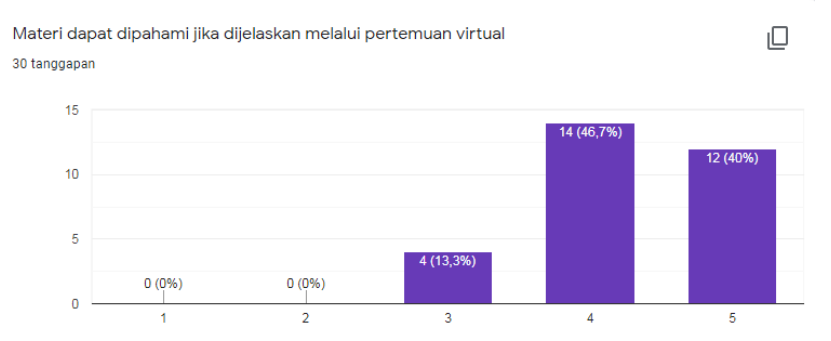
Gambar 1 Hasil Survei Manfaat Pertemuan Virtual dalam Pembelajaran Daring

Di sisi lain, berdasarkan hasil wawancara terhadap mahasiswa juga diketahui bahwa buku ajar dan penjelasan secara virtual saja tidak cukup untuk membuat mahasiswa memahami materi yang diberikan. Mahasiswa cenderung memerlukan penjelasan tambahan dari dosen terutama dengan mengulang penjelasan di kelas daring melalui video/rekaman selama pembelajaran berlangsung. Pada umumnya, media pembelajaran diperlukan dalam suatu pembelajaran sebagai sarana untuk 
menampilkan materi secara visual agar lebih mudah dipahami oleh peserta didik (Agustiningsih \& Pamungkas, 2018).

Gambar 2 berikut menunjukkan bahwa hasil survei yang dilakukan juga memperkuat adanya kebutuhan akan video pembelajaran pada mata kuliah Program Linier. Berdasarkan survei tersebut, diketahui bahwa $33,3 \%$ mahasiswa sangat setuju, 30\% mahasiswa setuju, dan 13,3\% mahasiswa cukup setuju bahwa pembelajaran secara daring melalui forum diskusi pada LMS/SPADA tidak cukup untuk mengakomodasi keinginan belajar mahasiswa.

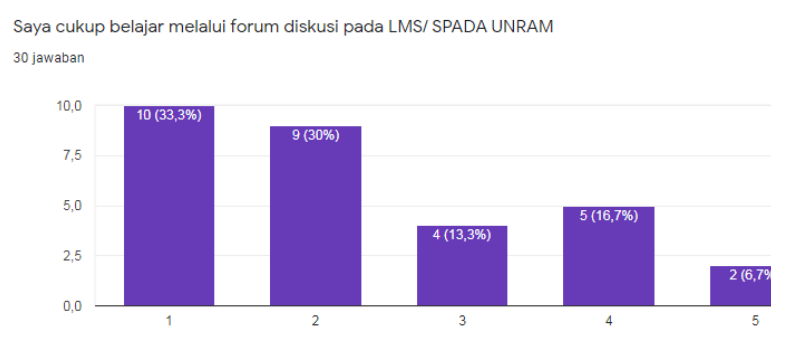

Gambar 2 Jawaban Mahasiswa tentang Forum Diskusi di LMS/SPADA

Hasil survei seperti yang ditunjukkan pada Gambar 3 juga menunjukkan bahwa $60 \%$ mahasiswa sangat setuju dan 33,3\% mahasiswa setuju bahwa diperlukan media pembelajaran lain untuk setiap materi yang ada pada mata kuliah Program
Linier. Media pembelajaran seperti video pembelajaran lebih dapat menarik minat seseorang dalam belajar dibandingkan hanya membaca dari buku atau sumber belajar yang bersifat diam (Fadhli, 2015). Sejalan dengan hal tersebut, hasil penelitian Nurwahidah dkk (2021) juga menunjukkan bahwa penggunaan video pembelajaran dapat meningkatkan motivasi dan prestasi belajar mahasiswa. Hal ini disebabkan oleh penayangan video pembelajaran dapat membuat mahasiswa seolah turut serta merasakan pembelajaran secara langsung sehingga materi lebih mudah dipahami.

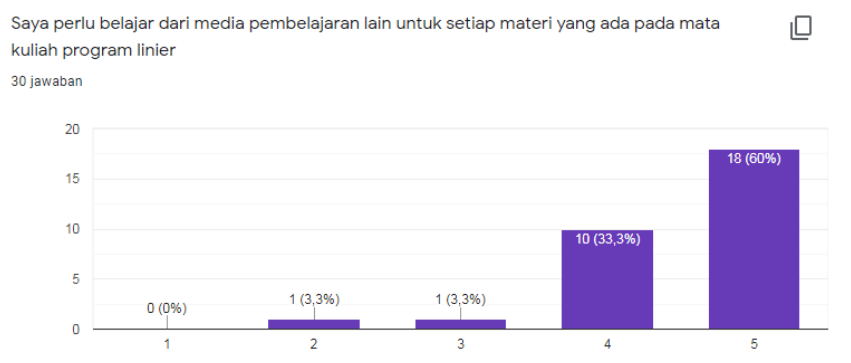
Gambar 3 Jawaban Mahasiswa tentang Forum Diskusi di LMS/SPADA

Garis besar rancangan video pembelajaran pada mata kuliah Program Linier

Video pembelajaran efektif digunakan sebagai media pembelajaran selama masa pandemi Covid-19 (Ridha dkk, 2021). Hal ini 
dikarenakan video pembelajaran dapat mempermudah seseorang dalam memahami apa yang disampaikan dalam video tersebut serta membuat belajar menjadi lebih menarik, efektif, dan efisien. Lebih lanjut, video pembelajaran yang akan dikembangkan dalam penelitian ini berpusat pada mata kuliah Program Linier dengan sasaran audience adalah mahasiswa Program Studi Pendidikan Matematika. Oleh karena itu, konten yang disajikan akan menyesuaikan dengan silabus, RPS, karakteristik mahasiswa, hingga modul yang tersedia, sehingga adanya video pembelajaran ini akan semakin mendukung tercapainya CPMK pada mata kuliah Program Linier.

Berdasarkan hasil analisis silabus, RPS, dan modul mata kuliah Program Linier serta observasi proses pembelajaran daring yang telah terlaksana pada semester yang lalu, maka terdapat beebrapa point yang menjadi garis besar video pembelajaran yang dikembangkan.

1. Video pembelajaran akan terbagi dalam beberapa bagian untuk setiap bab materi pada modul.

2. Bagian-bagian video dapat dibagi menjadi bagian video yang lebih kecil dengan mempertimbangkan subbab pada materi di modul.

3. Video pembelajaran akan disertai dengan evaluasi yang dibuat secara interaktif melalui platform lain seperti quizizz, kahoot, dan sebagainya.

Bagian awal setiap video pembelajaran ditujukan agar mahasiswa mengetahui tujuan pembelajaran yang akan dicapai dari video yang ditonton. Sedangkan bagian inti membahas lebih mendalam tentang materi, misal berupa penjelasan hingga semacam tutorial untuk menyelesaikan masalah program linier dengan berbagai metode. Hal ini dilakukan agar lebih mempermudah mahasiswa memahami materi dan menerapkan metode-metode penyelesaian masalah program linier dengan melihat, mengamati dan dapat meniru langkah penyelesaian secara langsung jika dibandingkan dengan hanya membaca dari modul. Sebagai tambahan, dengan pembagian video menjadi beberapa bagian, diharapkan agar video pembelajaran yang dikembangkan dapat lebih fokus dalam mencapai tujuan pembelajaran yang dimaksud. 
Video pembelajaran juga diberikan akses untuk evaluasi pembelajaran yang dapat dilakukan oleh mahasiswa secara mandiri dengan berbantuan platform kuis interaktif. Bagian ini penting agar mahasiswa dapat mengetahui sejauh mana ketercapaian pembelajaran yang dilakukan setelah menonton video pembelajaran. Selain itu, pemilihan kuis secara interaktif ini menjadi pertimbangan agar video pembelajaran yang dikembangkan lebih menarik dan dapat memotivasi minat belajar mahasiswa.

\section{E. Kesimpulan}

Berdasarkan hasil analisis data diperoleh bahwa kemampuan mahasiswa Prodi Pendidikan Matematika dalam menyelesaikan masalah program linier setelah diajarkan secara daring masih tergolong rendah. Kurangnya media pembelajaran berbentuk video pembelajaran menjadi salah satu penyebab yang akan ditindaklanjuti dalam penelitian ini. Oleh karena itu, dapat disimpulkan bahwa penting untuk mengembangkan video pembelajaran sebagai pendamping modul mata kuliah Program Linier.
Penelitian pengembangan yang dilakukan oleh peneliti masih terbatas pada video pembelajaran sebagai penunjang modul mata kuliah Program Linier. Oleh karena itu, diharapkan adanya pengembangan dalam bentuk media pembelajaran lain ataupun pengembangan yang serupa untuk mata kuliah lain yang semakin memperkaya sarana penunjang pembelajaran kepada mahasiswa.

\section{DAFTAR PUSTAKA}

Agustini, K., \& Ngarti, J. G. (2020). Pengembangan Video Pembelajaran untuk Meningkatkan Motivasi Belajar Siswa Menggunakan Model R \& D. Jurnal Ilmiah Pendidikan Dan Pembelajaran, 4(April 2020), 6278.

https://ejournal.undiksha.ac.id/inde x.php/JIPP/article/download/18403 $/ 14752$

Agustiningsih, N., \& Pamungkas, S. (2018). Analisis Kebutuhan Pengembangan Media Pembelajaran Video Candi Muara Jambi Berbasis Sejarah Lokal Pada Mata Kuliah Sejarah Indonesia. Diakronika, 18(1), 54-64. https://doi.org/10.24036/diakronika/ vol18-iss $1 / 62$

Annur, M. F., \& Hermansyah, H. (2020). Analisis Kesulitan Mahasiswa Pendidikan Matematika dalam Pembelajaran Daring pada 
Masa Pandemi Covid-19. Jurnal Kajian, Penelitian Dan Pengembangan Kependidikan, 11(2), 195-201.

Apsari, R. A., Sariyasa, Prayitno, S., Wulandari, N. P., \& Triutami, T. W. (2020). Analisis Kebutuhan Pengembangan Buku Ajar English For Mathematics. Jurnal Pendidikan Dan Kebudayaan Missio, 12(2), 80-86.

Candralaela, F., Jubaedah, Y., \& Ningsih, M. P. (2017). Penerapan Video Pembelajaran Untuk Peningkatan Kompetensi Pekerjaan Sosial Pada Peserta Didik Di Smkn 15 Bandung. FamilyEdu: Jurnal Pendidikan Kesejahteraan Keluarga, 4(2), 8292.

Fadhli, M. (2015). Pengembangan Media Pembelajaran Berbasis Video Kelas IV Sekolah Dasar. Jurnal Dimensi Pendidikan Dan Pembelajaran, 3(1), 24-29. https://doi.org/10.24269/dpp.v3i1.1 57

Lu'luilmaknun, U., Salsabila, N. H., Junaidi, J., Wulandari, N. P., \& Apsari, R. A. (2020). Pemanfaatan Media Pembelajaran Matematika Berbasis Teknologi: Persepsi Siswa Sma. Mathematic Education And Aplication, 2(1), 1-7.

Nasrah, N., \& Muafiah, A. (2020). Analisis Motivasi Belajaar dan Hasil Belajar Daring Mahasiswa Pada Masa Pandemik Covid-19. Jurnal Riset Pendidikan Dasar, 3(2), 207213.

Nurrita, T. (2018). Pengembangan Media Pembelajaran untuk Meningkatkan Hasil Belajar Siswa.
Misyikat, 3(1), 171-187.

Nurwahidah, C. D., Zaharah, Z., \& Sina, I. (2021). Media Video Pembelajaran dalam Meningkatkan Motivasi dan Prestasi Mahasiswa. Rausyan Fikr: Jurnal Pemikiran Dan Pencerahan, 17(1), 118-139. https://doi.org/10.31000/rf.v17i1.41 68

Plomp, T., \& Nieveen, N. (2010). An introduction to educational design research. Axis Media-ontwerpers.

Purbayanti, H. S., Ponoharjo, P., \& Oktaviani, D. N. (2020). Analisis Kebutuhan Video Pembelajaran Matematika pada Pandemi Covid19. JIPMat, 5(2), 165-172. https://doi.org/10.26877/jipmat.v5i2 .6693

Purwanti, B. (2015). Pengembangan Media Video Pembelajaran Matematika dengan Model Assure. Jurnal Kebijakan Dan Pengembangan Pendidikan, 3(1), 42-47.

http://ejournal.umm.ac.id/index.php /jmkpp/article/view/2194

Ridha, M., Firman, \& Desyandri. (2021). Efektifitas Penggunaan Media Video pada Pembelajaran Tematik Terpadu di Sekolah Dasar Saat Pandemi Covid-19. Jurnal Pendidikan Tambusai, 5(1), 154162.

https://jptam.org/index.php/jptam/a rticle/view/925

Salsabila, N. H., Wulandari, N. P., Lu'luilmaknun, U., Triutami, T. W., \& Handican, R. (2020). Pandangan Mahasiswa Pendidikan Matematika: Apakah Siswa akan Mudah Belajar dengan Permainan Edukasi? Jurnal Karya Pendiidkan 
Matematika, 7(2), 1-5.

Supriyono. (2018). Pentingnya Media

Pembelajaran untuk Meningkatkan Minat Belajar Siswa SD.

Edustream: Jurnal Pendidikan Dasar, II(1), 43-48. https://journal.unesa.ac.id/index.ph p/jpd/article/view/6262/3180

Wulandari, N. P., Novitasari, D., Junaidi, J., \& Baidowi, B. (2021). Pandangan Mahasiswa: Pentingnya Kemampuan Information and Communication Technology (ICT) bagi Calon Guru Matematika. Jurnal Pendidikan Matematika, 9(3), 266-275. https://doi.org/http://dx.doi.org/10.2 3960/mtk/v9i3.pp266-275

Wulandari, N. P., Safitri, A. S., Apsari, R. A., Junaidi, J., \& Lu'luilmaknun, U. (2020). Pengembangan Lembar Kegiatan Siswa untuk Meningkatkan Kemampuan Number Sense Siswa. SAP (Susunan Artikel Pendidikan), 4(3), 215-222.

https://doi.org/10.30998/sap.v4i3.6 284 